\title{
PROSEDUR PENGAMBILAN KEPUTUSAN DI LEMBAGA PENDIDIKAN TINGGI DI ERA REVOLUSI INDUSTRI 4.0
}

\author{
Biqrotul Azizah ${ }^{1}$ \\ Universitas Islam Negeri Sunan Ampel \\ bikro.azizah@gmail.com \\ Imam Syafi' $\mathrm{i}^{2 *}$ \\ Universitas Islam Negeri Sunan Ampel \\ Korespondensi: imamsyafii.iwa@gmail.com
}

\begin{abstract}
This article aims to describe the process of making and effective methods for the dissemination of decision results in the Industrial Revolution 4.0 era. This research uses library research taken from scientific journals and relevant literature. The results showed that the most effective decision making process was a combination of top-down and bottomup with formal decision-making mechanisms or decisions. Decision making formally involves leaders and subordinates and adjusted to the output of the meeting. The dominant dissemination mechanism is traditional dissemination through meetings and through social networks. The implications of the results of this study indicate that the formal process of decision making through public meetings or limited meetings is still the choice of the decision making process so that this traditional model provides space for all elements involved to participate and provide constructive advice for effective decision making.
\end{abstract}

Keywords: Decision Making Proces; Mechanism; Socialization; Higher Education

\section{PENDAHULUAN}

Proses pengambilan keputusan dalam sebuah organisasi menjadi salah satu topik penting yang dibahas oleh berbagai peneliti, penulis dan pemerhati pendidikan bidang budaya organisasi. Proses pengambilan keputusan dalam sebuah organisasi mencerminkan budaya dan ciri khas sebuah organisasi. Organisasi yang sehat sangat ditentukan oleh salah satunya proses pengambilan keputusannya, terutama organisasi yang berada di era revolusi industri sekarang ini.

Pengambilan keputusan merupakan suatu kegiatan yang berhubungan dengan proses menentukan suatu pilihan di antara banyaknya tantangan dan pilihan. Oleh karena itu, suatu organisasi yang memiliki budaya yang sehat, kuat dan profesional menempatkan proses pengambilan keputusan menjadi momentum inti dalam rangkaian kegiatan organisasi.

Konsep tentang mekanisme pengambilan keputusan telah banyak diteliti oleh berbagai peneliti di dunia. Proses pengambilan keputusan dilakukan dengan dua cara: top-down dan bottom-up. Metode tersebut juga dipengaruhi oleh moral dan watak orang-orang yang tergabung dalam suatu organisasi.

Lebih lanjut, proses pengambilan keputusan dalam suatu organisasi perlu mengintegrasikan antara keduannya sehingga hasil keputusan yang diambil dapat 
dipertanggungjawabkan dan diterima banyak kalangan. Penggabungan metode proses pengambilan keputusan tersebut juga didukung oleh banyak peneliti.

Di sisi lain, proses pengambilan yang menjamin keadilan dan keberpihakan kepada semua ialah mekanisme bottom-up. Alasannya ialah banyak keputusan yang diambil oleh pimpinan tidak pernah melibatkan para bawahan sehingga sangat menguntungkan sebagian kecil kelompok dalam suatu organisasi. Demikian halnya, pengambilan keputusan melalui mekanisme bottom-up dapat mengakomodir banyak kepentingan arus kelompok marginal sehingga bisa menjadi pilihan yang tepat dalam setiap pengambilan keputusan.

Penelitian tentang budaya organisasi di dunia telah banyak dilakukan. Namun di Indonesia, penelitian tentang budaya organisasi masih perlu dilakukan karena belum banyak penelitian khususnya terkait dengan proses pengambilan keputusan serta strategi yang efektif untuk melakukan diseminasi keputusan terhadap anggota organisasi. Oleh karena itu, artikel ini bertujuan untuk memberikan deskripsi tentang mekanisme pengambilan keputusan di Lembaga Pendidikan Tinggi dan strategi desiminasi kegiatan tersebut. Artikel ini memberi kontribusi terhadap budaya organisasi dalam hal pengambilan keputusan dan diharapkan dapat menambah khasanah pengetahuan dan kajian baru baik di tingkat nasional maupun internasional di bidang pengambilan keputusan dalam suatu organisasi.

\section{METODE PENELITIAN \\ Desain Penelitian}

Desain penelitian yang digunakan dalam penelitian ini adalah penelitian deskriptif kualitatif. Penelitian deskriptif kualitatif berkaitan dengan apa dan bagaimana fenomena yang diteliti yang berasal dari sumber literatur. Penelitian deskriptif kualitatif ini sangat tepat digunakan untuk menganalisis proses pengambilan keputusan dalam sebuah organisasi terutama dalam konteks perguruan tinggi.

\section{Instrumen Penelitian}

Penelitian ini mengungkap secara mendalam tentang proses pengambilan keputusan dengan instrument literatur. Literatur yang relevan dikomparasi oleh penulis dan diambil yang paling relevan dengan tema penelitian.

\section{Langkah-langkah Pengumpulan Data}

Pengumpulan data melalui metode library research dengan beberapa langkah sebagai berikut: 1) mengidentifikasi literatur yang sesuai dengan tema penelitian; 2) mengomparasikan antara literatur satu dengan yang lain dan diambil yang paling relevan dengan tema penelitian; 3) menganalisis data-data yang sudah didapatkan dari literatur dan hasil analisis tersebut dimasukan ke dalam tulisan sebagai bagian dari hasil penelitian.

\section{Metode Analisis Data}


Data dari literatur dianalisis melalui perbandingan dengan literatur yang lain untuk melihat prosentase dan gambaran tentang proses pengambilan keputusan. Analisis data yang dilakukan pada penelitian menggunakan pendekatan tematik. Pendekatan tematik ialah pendekatan yang digunakan untuk melihat data secara keseluruhan, memberi kode-kode tertentu terhadap data yang dianggap penting, memberi tema terhadap kode-kode tersebut, mengumpulkan sub tema untuk dijadikan bahan dalam menentukan kategori umum terkait data penelitian, dan akhirnya semua tema-tema tersebut dimasukan ke dalam tulisan sebagai bagian dari hasil penelitian.

Keputusan merupakan hasil pemecahan dalam suatu masalah yang harus dihadapi dengan tegas. Dalam Kamus Besar Ilmu Pengetahuan pengambilan keputusan (decision making) didefinisikan sebagai pemilihan keputusan atau kebijakan yang didasarkan atas kriteria tertentu. Proses ini meliputi dua alernatif atau lebih karena seandainya hanya terdapat satu alternatif tidak akan ada satu keputusan yang akan diambil.

Pengambilan keputusan merupakan salah satu bentuk perbuatan berpikir dan hasil dari suatu perbuatan itu disebut keputusan. Menurut Suharnan, pengambilan keputusan adalah proses memilih atau menentukan berbagai kemungkinan diantara situasi-situasi yang tidak pasti. Pembuatan keputusan terjadi di dalam situasi-situasi yang tidak pasti. Pembuatan keputusan terjadi di dalam situasi-situasi yang meminta seseorang harus membuat prediksi kedepan, memilih salah satu diantara dua pilihan atau lebih, membuat estimasi (prakiraan) mengenai frekuensi prakiraan yang akan terjadi.

Proses pengambilan keputusan di Lembaga Pendidikan Tinggi tidak lepas dari peran seorang pemimpin sehingga tercipta keputusan yang sesuai dengan tujuan organisasi.

Hal senada Weber juga mengemukakan, bahwa kepemimpinan menurut Max Weber dalam Ali Azis terdapat tiga macam wewenang: a) wewenang kharismatis, yaitu wewenang yang bersandar pada ketaatan terhadap seorang individu yang luar biasa, yakni pemimpin atas kebijakan berupa kepercayaan pribadi dalam dirinya dan kualitasnya yang patut dicontoh. Otoritas ini cenderung nonrasional, afektif dan emosional serta bersandar kuat pada kualitas dan karakteristik pemimpin; b) wewenang tradisional, yaitu suatu wewenang yang berdasarkan pada kepercayaan yang ditetapkan dalam kesucian status yang dilakukan waktu lampau. Kepatuhan diperlihatkan pada otoritas yang secara tradisional memiliki kedudukan suci dan orang yang mengisi kedudukan tersebut mewarisi otoritas yang ditetapkan oleh kebiasaan waktu lampau; c) wewenang legal, yaitu wewenang yang didasarkan pada aturan yang diundangkan yang dapat diubah melalui prosedur formal. Kepatuhan diperlihatkan bukan pada seseorang melainkan pada peraturan atau undang-undang.

Berdasarkan beberapa definisi diatas, maka pengambilan keputusan (decision making) merupakan suatu proses pemikiran dari beberapa pilihan alternatif 
yang akan dihasilkan mengenai prediksi kedepan yang melibatkan pimpinan dan anggota suatu oranisasi.

\section{HASIL DAN PEMBAHASAN}

\section{Proses Pengambilan Keputusan di Lembaga Pendidikan Tinggi}

Proses pengambilan keputusan menjadi tema yang sangat menarik untuk dibahas karena berdasarkan hasil data yang diperoleh oleh penulis, terdapat tiga mekanisme proses pengambilan keputusan yakni: top-down, bottom up dan gabungan dari top-down dan bottom-up.

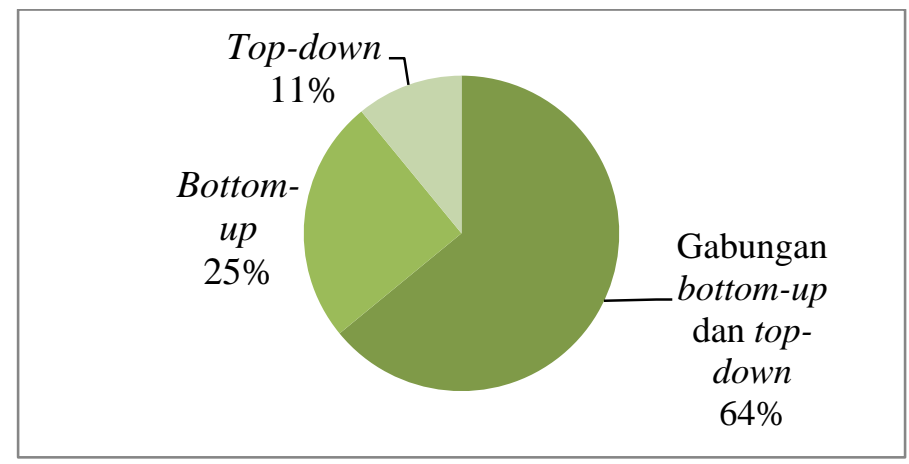

Gambar 1. Proses Pengambilan Keputusan

Sumber : JEKPEND Vol 2 No. 22019

Mekanisme yang paling dominan ialah kombinasi antara top-down dan bottom-up. Hal ini berarti bahwa pihak civitas akademika terutama dalam Lembaga Pendidikan Tinggi sangat mengharapkan keterlibatan pihak pimpinan dan bawahan dalam proses pengambilan keputusan terutama yang menyangkut hajat dan kepentingan bersama. Dari statistik di atas juga menunjukan bahwa gabungan ini harus menjadi pilihan utama dan panduan bagi pimpinan dalam suatu organisasi dalam proses pengambilan keputusan.

Mekanisme top-down ialah proses pengambilan keputusan yang hanya melibatkan pejabat tinggi dan diinisiasi oleh mereka. Proses ini sangat eksklusif dan dihadiri oleh anggota yang terbatas. Proses ini juga hanya dilakukan untuk mengambil keputusan-keputusan yang mendesak sehingga dapat dicapai kesepakatan dalam waktu singkat dan dilaksanakan dalam waktu yang mendesak juga. Sedangkan proses keputusan yang berasal dari arus bawah bottom-up sedikit diminati oleh para civitas akademik karena proses ini sangat memerlukan energi yang banyak, mekanisme yang cukup panjang dan proses yang lebih lama.

Berdasarkan referensi yang penulis dapat, dalam penelitian ini menunjukan bahwa proses pengambilan keputusan ialah penggabungan bottom-up dan top down. 
Biqrotul Azizah, Imam Syafi $i$

Prosedur Pengambilan Keputusan Di Lembaga Pendidikan Tinggi Di Era Revolusi

Beberapa alasan yang dikemukan oleh civitas akademika terkait pentingnya gabungan antara bottom-up dan top down antara lain:

Tabel 1. Pentingnya proses Pengambilan Keputusan

\begin{tabular}{|c|c|}
\hline $\mathbf{C A}$ & Pandanganyya \\
\hline 1 & $\begin{array}{l}\text { Ada masalah tertentu pimpinan mengambil keputusan sendiri dan } \\
\text { memberikan instruksi kepada bawahannya, akan tetapi pada } \\
\text { masalah tertentu, pimpinan menerima masukan dari bawahannya. }\end{array}$ \\
\hline 2 & $\begin{array}{l}\text { Dikembalikan ke kondisi yang terjadi, jika itu merupakan aturan } \\
\text { dari pimpinan maka akan disosialisasikan ke unit-unit di bawahnya. } \\
\text { Tetapi jika terkait dengan masalah akademik mahasiswa maka akan } \\
\text { diselesaikan pada tingkat prodi dengan pembimbing akademik } \\
\text { dilanjutkan ke pihak fakultas. }\end{array}$ \\
\hline 3 & $\begin{array}{l}\text { Dalam penentuan rencana strategis dan rencana operasional fakultas } \\
\text { serta program studi, visi dan misinya bersumber dari visi dan misi } \\
\text { universitas (top-down), kemudian program kerjanya berdasarkan } \\
\text { kebutuhan program studi serta fakultas (bottom-up). }\end{array}$ \\
\hline 4 & $\begin{array}{l}\text { Keputusan pengajuan kuota penerimaan maba oleh kaprodi melalui } \\
\text { rapat fakultas tidak sesuai dengan kenyataan setelah melalui pusat } \\
\text { atau pucuk pimpinan. }\end{array}$ \\
\hline 5 & $\begin{array}{l}\text { Keputusan tentang pelaksanaan PMB (penerimaan mahasiswa baru) } \\
\text { di fakultas masing masing sudah ditentukan jadwal dan waktu } \\
\text { pelaksanaanya secara serentak, namun untuk teknis kegiatan } \\
\text { diserahkan kepada panitia pelaksana kegiatan PMB. }\end{array}$ \\
\hline
\end{tabular}

Contoh tindak lanjut keputusan yang bersifat penggabungan pengambilan keputusan yang bersifat bottom-up dan top-down ialah terkait penerimaan mahasiswa baru, kebijakan penentuan program kerja prioritas sebuah institusi, penentuan UKT dan aktivitas lembaga kemahasiswaan. Civitas akademika yang terlibat dalam penelitian menjelaskan bahwa kombinasi proses pengambilan keputusan sangat penting karena tidak semua keputusan harus bersifat top-down dan sebaliknya tidak semua keputusan harus bersifat bottom-up. Oleh karena itu, kelihaian dan kepemimpinan yang baik, sehat dan profesional akan mampu melihat dan memilih mekanisme pengambilan keputusan yang tepat yang sesuai dengan situasi, keperluan dan kepentingan organisasi saat itu.

Proses pengambilan keputusan dalam suatu organisasi yang menggabungkan dua mekanisme top-down dan bottom up memiliki implikasi pada suatu organisasi. Implikasi pengambilan keputusan top-down selalu mempertimbangkan mekanisme standar dan etika organisasi, sedangkan mekanisme bottom-up selalu mempertimbangkan aspek-aspek yang dapat melahirkan standar atau konsep yang 
menjadi landasan organisasi. Lebih lanjut lagi, penggabungan proses pengambilan tentang suatu hal dalam sebuah organisasi biasa dilakukan, karena mekanisme pengambilan keputusan top-down cenderung memperhatikan macro level. Macro level yang dimaksud ialah mekanisme pengambilan keputusan yang memperhatikan suara yang lebih banyak dan kepentingan yang lebih luas. Sedangkan proses pengambilan keputusan bottom-up cenderung memperhatikan micro level, yakni kepentingan sekelompok orang dalam suatu organisasi. Mekanisme pengambilan keputusan top-down bersifat sentralistik dan mekanisme pengambilan keputusan bottom-up bersifat disentralisasi. Sentralistik yang dimaksud ialah proses pengambilan keputusan yang dilakukan pimpinan utama atau level dekan dan wakil dekan pada tingkat fakultas. Sedangkan mekanisme keputusan yang bersifat disentralisasi yakni diibaratkan keputusan yang dibuat pada tingkat program studi, yang kemudian disahkan oleh anggota senat dan pimpinan fakultas.

Implikasi lainnya ialah hasil pengambilan keputusan bottom-up memerlukan proses yang lebih panjang dan kompleks untuk dilaksanakan karena perlu persetujuan pimpinan organisasi. Tapi kelebihan dari keputusan yang diambil melalui mekanisme bottom-up ialah memberikan keleluasaan kepada bawahan untuk memodifikasi cara untuk melaksanakan hasil keputusan. Sedangkan hasil keputusan yang diambil dari mekanisme top-down tidak memiliki tantangan yang rumit untuk dilaksanakan, namun memiliki tantangan dalam hal cara untuk mendorong bawahan agar memiliki motivasi dan semangat yang optimal dalam menjalankan hasil keputusan yang dibuat melalui mekanisme top-down.

\section{Metode Efektif untuk Sosialisasi Hasil Keputusan}

Hasil penelitian menunjukan bahwa metode yang efektif dan desiminasi hasil keputusan rapat ialah melalui rapat, jejaring sosial, komunikasi lisan secara individu dan email. 


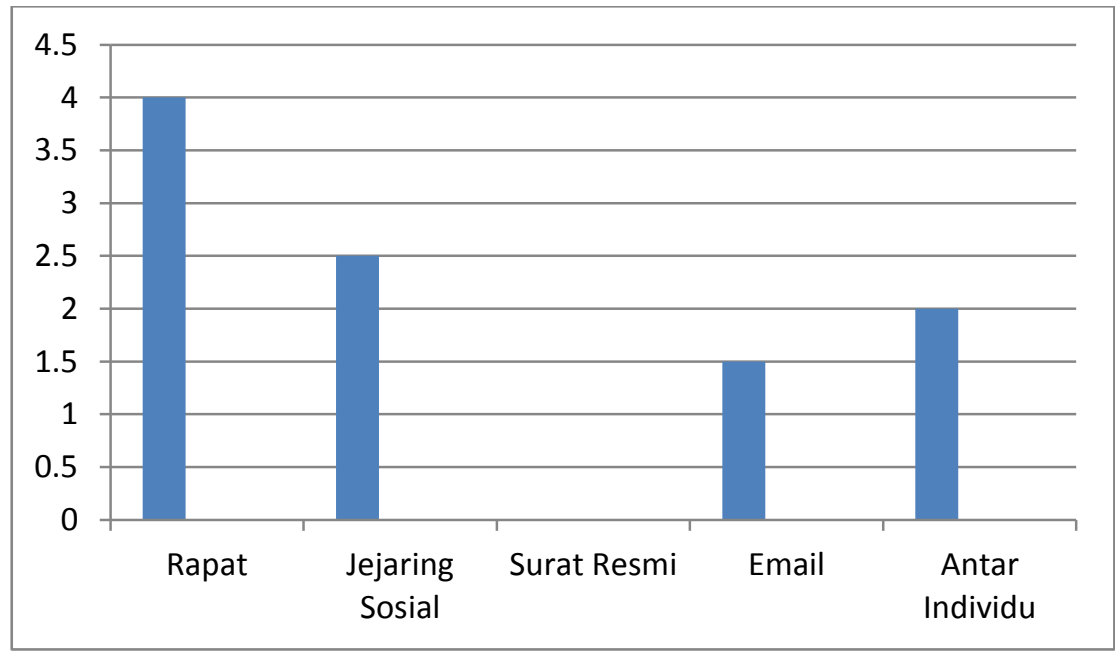

Gambar 2. Mekanisme Desiminasi Hasil Keputusan

Sumber : JPIH Vol 4. No. 12015

Berdasarkan hasil analisis data yang penulis peroleh dari referensi menunjukan bahwa mekanisme yang paling diminati oleh anggota Lembaga Pendidikan Tinggi dalam sosialisasi hasil keputusan ialah mekanisme rapat. Semua hasil keputusan harus didesiminasi lebih dahulu melalui rapat kemudian disosialisasikan dalam bentuk lain. Grafik di atas menunjukan bahwa menghadirkan semua elemen dalam suatu musyawarah atau rapat masih menjadi cara yang efektif untuk desiminasi hasil keputusan bersama karena dengan melalui rapat maka semua elemen yang terlibat dapat memperhatikan dan menyimak hasil keputusan tersebut. Hal tersebut dapat mengurangi distorsi, bias, dan interpretasi lain terhadap hasil keputusan. Hal yang menarik lainnya ialah tidak satupun civitas akademika yang memilih surat resmi sebagai bentuk sosialisasi hasil keputusan. Hal ini bisa saja diartikan bahwa surat resmi terlihat lamban, dan kurang praktis untuk digunakan dalam sosialisasi hasil keputusan. Namun demikian, untuk pengarsipan dan dokumentasi organisasi, surat resmi bisa menjadi salah satu pilihan yang tetap tersedia dalam suatu organisasi.

Sosialisasi hasil keputusan melalui rapat formal memberi beberapa kelebihan antara lain: a) peserta rapat dapat secara demokratis mempertanyakan hasil keputusan rapat jika terdapat kejanggalan dan ketidakjelasan; b) peserta rapat dapat secara langsung memberikan tanggapan atau solusi terhadap isu yang diangkat; c) peserta rapat dapat memilih pilihan yang terbaik di antara pilihan yang tersedia; dan d) peserta rapat dapat memberikan hasil analisa dan review terhadap pilihan yang telah diambil. Di samping itu, mekanisme diseminasi hasil keputusan melalui rapat formal memiliki sifat birokratis, hirarki dan paternaslitik. 
Sedangkan keuntungan lain dari proses diseminasi hasil keputusan melalui rapat ialah mencegah bias informasi karena semua pihak terkait telah hadir bersama untuk mendengarkan hasil keputusan. Hal ini memberikan keuntungan terkait efisiensi waktu, tenaga dan mengurangi mekanisme birokrasi dalam suatu organisasi. Mekanisme tersebut mencerminkan gaya kepemimpinan dalam organisasi, ciri khas kepemimpinan dan visi futuristik kepemimpinan dalam organisasi. Proses diseminasi hasil keputusan tersebut juga mencerminkan budaya suatu organisasi.

Sesuai hasil temuan di atas, maka interpretasi mekanisme proses pengambilan keputusan dan sosialisasinya dapat tergambar dalam grafik di bawah ini:

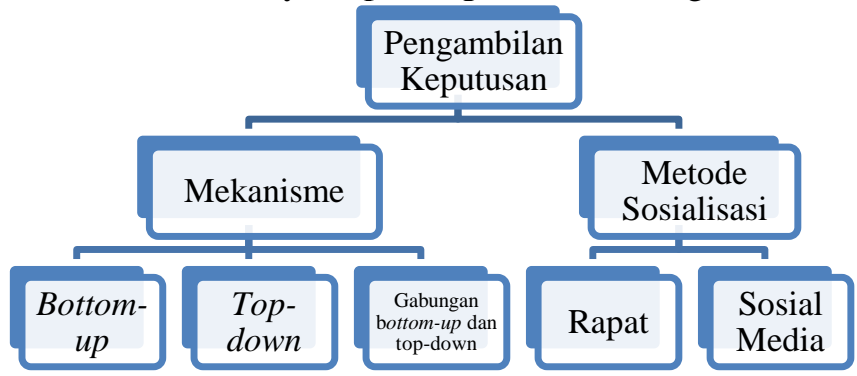

Gambar 3. Pengambilan Keputusan: Mekanisme dan Metode Sosialisasinya Sumber: hasil olahan peneliti

Dari bagan di atas terlihat bahwa mekanisme pengambilan keputusan disesuaikan dengan kebutuhan dan keperluan suatu organisasi. Jika keputusan yang mengharuskan hanya elemen pimpinan saja, maka proses pengambilan keputusan dilakukan secara top-down, yakni diinisiasi oleh pimpinan dan kemudian diteruskan dan disosialisasikan kepada bawahan. Proses pengambilan keputusan menjadi pilar yang sangat penting untuk keberlanjutan perjalanan organisasi untuk masa yang akan datang. Implikasinya ialah mekanisme pengambilan keputusan yang efektif dalam konteks Indonesia ialah melalui mekanisme gabungan top-down dan bottom-up. Mekanisme tersebut memiliki implikasi kepada organisasi dalam dunia pendidikan yakni universitas, institut, sekolah tinggi, politeknik dan akademi komunitas. Implikasinya ialah:

a. Pemimpin suatu unit perlu memiliki pengetahuan dan keterampilan dalam mengambil keputusan sehingga keputusan yang diambil dapat memecahkan masalah yang dihadapi organisasinya.

b. Pemimpin dalam suatu organisasi perlu memiliki tanggung jawab dan keberanian untuk mengambil resiko atas segala keputusan yang diambil sehingga jika ada efek negatif dari keputusan, maka pemimpin tidak menyalahi bawahannya.

c. Pemimpin yang baik dan visioner selalu memperhatikan, mendengarkan dan memahami aspirasi bawahannya sehingga keputusan yang diambil sesuai dengan tuntutan kebutuhan bersama. 
d. Pemimpin perlu mensosialisasikan hasil keputusan bersama melalui mekanisme rapat formal dan jejaring sosial, disesuaikan dengan kondisi dan aturan yang berlaku dalam organisasi tersebut.

\section{KESIMPULAN}

Berdasarkan temuan di atas, maka beberapa kesimpulan penting dalam penelitian ini ialah:

1. Mekanisme pengambilan keputusan terbaik ialah gabungan antara top-down dan bottom-up. Mekanisme ini berarti bahwa proses pengambilan suatu keputusan tidak hanya mendengarkan suara pimpinan saja, melainkan juga mendengarkan suara bawahan sehingga hasil keputusan yang diambil merupakan representase antara kaum elit dan kaum marginal serta merupakan aspirasi bersama dalam suatu organisasi.

2. Metode sosialisasi hasil keputusan yang paling efektif dalam penelitian ini ialah mekanisme rapat. Melalui rapat yang melibatkan pimpinan atau bawahan saja ataupun melibatkan kedua-keduanya akan sangat efektif untuk mendesiminasikan hasil keputusan rapat. Karena melalui rapat, hasil keputusan yang disampaikan bisa didengarkan langsung sehingga akan mengurangi interpretasi yang berbeda dari setiap orang atas hasil keputusan rapat yang telah diputuskan. 


\section{DAFTAR PUSTAKA}

Abduh, Hasbi. (2015). Pengambilan Keputusan di Lembaga Pendidikan. Jurnal Pendidikan Islam Hikmah. 4(1): 26-30.

Aziz, Muhammad, Amirullah Abduh Kajian Kebijakan Proses Pengambilan Keputusan di Perguruan Tinggi di Era Revolusi Industri. Jurnal Ekonomi dan Pendidikan. 2(2): 30-35

Biesbroek, R., Dupuis, J., Jordan, A., Wellstead, A., Howlett, M., Cairney, P., Davidson, D. (2015). Opening up the black box of adaptation decisionmaking. Nature Climate Change. 5(6), 493.

Braun, V., \& Clarke, V. (2006). Using thematic analysis in psychology. Qualitative Research in Psychology. 3(2): 77-79.

Fathin, Fariza. (2016). Pengambilan Keputusan pada Remaja yang Mengalami Kehamilan di Luar Nikah (Studi di Kabupaten Mojokerto Jawa Timur). repository.unair.ac.id. (repository.unair.ac.id/68251/2/Fis.S.59.17\%20.\%20Fat.p\%20\%20JURNAL.pdf diakses pada 5 Juni 2020).

Hornung, S., Rousseau, D. M., Glaser, J., Angerer, P., \& Weigl, M. (2010). Beyond top-down and bottom-up work redesign: Customizing job content through idiosyncratic deals. Journal of Organizational Behavior. 31(2-3): 187-190.

Kim, Y. H., Sting, F. J., \& Loch, C. H. (2014). Top-down, bottom-up, or both? Toward an integrative perspective on operations strategy formation. Journal of Operations Management. 32(7): 462-465.

Marchisotti, G. G., \& Almeida, R. L. De. (2018). Decision-making at the Firt Managment Level: The Interference of the Organizational Culture. Revista de Administração Mackenzie. 20(3): 1-3.

Syafi'i, Imam. (2017). Kepemimpinan Kiai Abdul Ghofur dalam pengembangan pendidikan entrepreneurship di Pondok Pesantren Sunan Drajat Lamongan. digilib.uinsby.ac.id. (digilib.uinsby.ac.id/19893/5/Bab\%202.pdf diakses pada 5 Juni 2020).

Turpin, S. M., \& Marais, M. (2004). Decisionmaking: Theory and practice. OriON. 20(2): 143 . 
Biqrotul Azizah, Imam Syafi $i$

Prosedur Pengambilan Keputusan Di Lembaga Pendidikan Tinggi Di Era Revolusi

Wallach, W., Allen, C., \& Smit, I. (2008). Machine morality: bottom-up and topdown approaches for modelling human moral faculties. Ai \& Society. 22(4): 565 . 